\title{
Studies on the small invertebrate plankton of the Sargasso Sea
}

\author{
Ruth Böttger* \\ Biologische Anstalt Helgoland (Zentrale); Notkestraße 31, D-2000 Hamburg 52, \\ Federal Republic of Germany
}

\begin{abstract}
During the German Eel Expedition in Spring 1979, the horizontal and vertical distribution of the invertebrate plankton was studied in the epipelagic zone of the western central Sargasso Sea, based on $55 \mu \mathrm{m}$ and $100 \mu \mathrm{m}$ mesh net samples. In the isothermal waters north of the thermal front, plankton biomass was on average 2-3 times higher than in the warmer stratified waters south of the front. With regard to the fraction of small invertebrates (nauplii and microcopepods) the differences in numerical abundance between the two areas were similar to those reported in the literature for other size ranges of organisms. No divergency was obvious in the plankton composition in terms of major taxonomic groups and size classes. In both parts of the area, organisms smaller than $400 \mu \mathrm{m}$, which form a fraction not quantitatively sampled by the conventional $200 \mu \mathrm{m}$ or $300 \mu \mathrm{m}$ mesh nets, accounted for $71-92 \%$ of the total number of organisms in the $55 \mu \mathrm{m}$ net samples and for more than $50 \%$ in the $100 \mu \mathrm{m}$ net samples. Average concentrations of the potential food supply for early larval fish stages in the upper $100 \mathrm{~m}$ appear to be comparable with values reported in the literature for areas well known for larval fish development, such as the California Current.
\end{abstract}

\section{INTRODUCTION}

The subtropical convergence or thermal front (Backus et al., 1969) is a characteristic feature of the Sargasso Sea, separating the central part into cooler, more productive northern parts and warmer, less productive southern parts. In the northern part, a thermal stratification of the euphotic zone is restricted to the summer period, when surface temperatures increase to more than $18^{\circ} \mathrm{C}$. In the southern part, the upper waters are vertically stratified all year round and generally remain at higher temperatures.

Corresponding to these differences in the temperature structure, several authors have observed north to south differences in the biota of the Sargasso Sea. Ryther \& Menzel $(1960,1961)$ reported that the net primary production in winter or springtime was significantly lower in the southern stratified waters than in the adjacent northern area. Differences between the North and South have also been investigated regarding the species abundance and composition of phytoplankton (Hụlburt, 1964), epipelagic copepods (Colton et al., 1975) and mesopelagic fishes (Backus et al., 1969), as well as the abundance of planktonic Foraminifera and Radiolaria (Cifelli \& Sachs, 1966).

\footnotetext{
* Present address: Institut für Hydrobiologie und Fischereiwissenschaft; Zeiseweg 9, D-2000
} Hamburg 50, Federal Republic of Germany 
In general, a decrease in abundance and/or biomass from north to south has been reported for alle these organisms, explained by the corresponding reduction in primary production (Backus et al., 1969) and by the differences in environmental conditions in the subsurface layers inhabited by migrating animals during the day (Colton et al., 1975).

During the Sargasso Sea Eel Expedition in Spring 1979 (Tesch, 1982), a plankton sampling program was carried out aboard R. V. "Friedrich Heincke". Special attention was paid to the small invertebrate component (nauplii and microcopepods) of the plankton community, which is a potential food source for larval fish. This paper presents results of studies on the horizontal and vertical distribution of the $0.1 \mathrm{~mm}$ mesh net plankton biomass on two north-south transects and provides information on the abundance and composition of the invertebrate plankton component from $0.1 \mathrm{~mm}$ and $0.05 \mathrm{~mm}$ mesh net samples at selected stations both north and south of the thermal front.

\section{METHODS}

Zooplankton samples were collected aboard the R. V. "Friedrich Heincke" between March 18 and March 28, 1979 at 36 stations located along four north-south transects between $31^{\circ} 30^{\prime} \mathrm{N}$ to $26^{\circ} 30^{\prime} \mathrm{N}$ and $51^{\circ} \mathrm{W}$ to $61^{\circ} \mathrm{W}$. The distance between the transects was about 80 nautical miles (nm). Along each transect, 7 to 11 stations were located, each $30 \mathrm{~nm}$ apart (Fig. 1). The geographic position of each station is given by Tesch (1982).

Vertical temperature profiles from 0-300 $\mathrm{m}$ were taken with an expandable bathythermograph (XBT) immediately after the plankton tows at each station. In addition, surface water temperature was measured continuously at a depth of $5 \mathrm{~m}$.

Two different types of plankton samplers were used. At each station, vertical hauls, integrating the upper $100 \mathrm{~m}$, were taken with an Apstein-net, which had an opening reduction cone with $0.02 \mathrm{~m}^{2}$ aperture and a mesh size of $55 \mu \mathrm{m}$. Since the analysis of these samples turned out to be extremely time consuming, only the northernmost and southernmost station of each transect has been included in the present study. A multiple opening-closing net (Weikert \& John, 1981) with $100 \mu \mathrm{m}$ mesh size was used to sample five consecutive depth strata between $0-200 \mathrm{~m}(0-25 \mathrm{~m}, 25-50 \mathrm{~m}$, and $50 \mathrm{~m}$ steps in the $50-200 \mathrm{~m}$ range) separately during one vertical tow. At each of the stations $555,553,564$ and $565 \mathrm{a}$, one additional tow was made from $500 \mathrm{~m}$ to the surface in $100 \mathrm{~m}$ steps. The sampler has an aperture of $0.25 \mathrm{~m}^{2}$; net changes were actuated from a deck unit according to the readings of a depth recorder. Due to heavy weather conditions at the beginning of the survey, $100 \mu \mathrm{m}$ mesh net samples can be considered quantitatively only along the two western transects, III and IV, and at Station 539 (Fig. 1, 2). The analysis, therefore, has been restricted to these stations.

The samples were preserved in a $4 \%$ formaldehyde-seawater solution buffered with hexamethylenetetramine. For sorting and further storage, they were transferred into a formalin-free preservative fluid containing $5 \%$ propylene glycol, $0.5 \%$ propylene phenoxetol and $94.5 \%$ filtered seawater (Steedman, 1976).

The total plankton biomass in the $100 \mu \mathrm{m}$ mesh net samples, not including molluscs and vertebrates, was determined by wet weight measurements. Each sample was concentrated on a preweighed $55 \mu \mathrm{m}$ mesh filter, rinsed with $10 \mathrm{ml}$ of $70 \%$ alcohol to remove interstitial water and drained under a slight vacuum for 5 seconds. The filter was 
placed in a closed plastic dish for weighing to avoid continuous evaporation during measurement (Beers, 1976). The weights, ranging from $50 \mathrm{mg}$ to $>1000 \mathrm{mg}$ per sample, were determined with a precision of $\pm 1 \mathrm{mg}$. Single large organisms, in most cases chaetognaths, large crustaceans or coelenterates, were weighed separately. Due to the removal of molluscs and vertebrates (larval fish and larvae of Branchiostoma), the actual biomass of the total zooplankton sampled is slightly underestimated; this is compensated for, to some extent, by a slight overestimation due to some contamination of samples with phytoplankton and detritus.

A more detailed evaluation of samples, providing information on the composition and abundance by major taxonomic groups and size categories, was restricted to northernmost and southernmost stations for comparison. The vertical distribution of the $100 \mu \mathrm{m}$ mesh net plankton down to a depth of $500 \mathrm{~m}$ was investigated at the stations $565 \mathrm{a}$ (day) and 564 (night) in the northern area, and at Stations 555 (day) and 553 (night) in the southern area. Additional information for the upper $100 \mathrm{~m}$ depth zone, including smaller sized organisms, has been derived from the $55 \mu \mathrm{m}$ mesh samples at the stations 523,541 (day) and 539, 564 (night) in the north and 532, 555 (day) and 530, 553 (night) in the south.

Planktonic organisms were identified to major taxonomic groups and counted in four different size categories: $<200 \mu \mathrm{m}, 200-400 \mu \mathrm{m}, 400-1200 \mu \mathrm{m}$ and $>1200 \mu \mathrm{m}$. Size classifications were made under a dissecting microscope with a magnification power of 25 and refer to total length or largest diameter of the specimens. Copepod length was measured excluding the furcal setae. The length of appendicularians recorded is the trunk length.

All abundance data presented in this paper refer to the metazoan fraction of the zooplankton only. Protozoans were not included in the counts, since they were usually entangled with phytoplankton, detritus or gelatinous material. Mucous material occurred in the samples down to $300 \mathrm{~m}$ in rather large amounts and made the sorting generally difficult. Copepod exoskeletons and dead copepods, which were distinguished from living material according to the criteria of Wheeler (1967) and Weikert (1977), were counted separately (100 $\mu \mathrm{m}$ mesh nets) or excluded and counted in selected samples only ( $55 \mu \mathrm{m}$ mesh nets).

The numbers of organisms in the $55 \mu \mathrm{m}$ mesh net samples, which could not be subdivided for counting, ranged between 1,800 and 33,000 per sample, representing the plankton content of $2.3 \mathrm{~m}^{3}$ of seawater. The filtered volume of the $100 \mu \mathrm{m}$ mesh nets ranged from $6.5-25 \mathrm{~m}^{3}$, according to the depth strata taken. Samples were divided into two size fractions by filtration through $500 \mu \mathrm{m}$ mesh gauze. The whole fraction was counted for larger sized organisms. In the smaller size fraction, the most abundant groups (copepods, nauplii and appendicularians) were estimated from subsamples. Only at greater depths, where plankton concentrations were low, were complete samples enumerated.

\section{RESULTS}

\section{Hydrography}

A general picture of the hydrographic situation in the Sargasso Sea in Spring 1979 is given by Wegner (1982), based on casts from a large number of stations over an extended 
area taken aboard the F. R. V. "Anton Dohrn". According to his results, the horizontal surface temperature gradients did not indicate the presence of the very pronounced thermal front that was observed during some earlier studies (Katz, 1969; Voorhis, 1969).

The continuous recording of surface temperatures on board the R. V. "Friedrich Heincke" showed that the maximum horizontal temperature gradient was located at about $30^{\circ} \mathrm{N}$ along Transects I and II, and somewhat farther south, at about $27-29^{\circ} \mathrm{N}$, along Transects III and IV, where the gradient was less pronounced (Fig. 1).

The vertical temperature distribution down to a depth of $300 \mathrm{~m}$ is shown in Figure 2 for all four transects. The most complete plankton data are available for Transects III and IV, where north of and at Stations 545 and 559, respectively, the water column was almost isothermal throughout the $0-200 \mathrm{~m}$ depth range, with temperature values of about $19^{\circ} \mathrm{C}$, varying not more than $\pm 0.5^{\circ} \mathrm{C}$. Southward, the surface temperatures increased to about $22^{\circ} \mathrm{C}$ within the sampled area, and a progressively increasing stratification in the upper $200 \mathrm{~m}$ depth range was indicated.

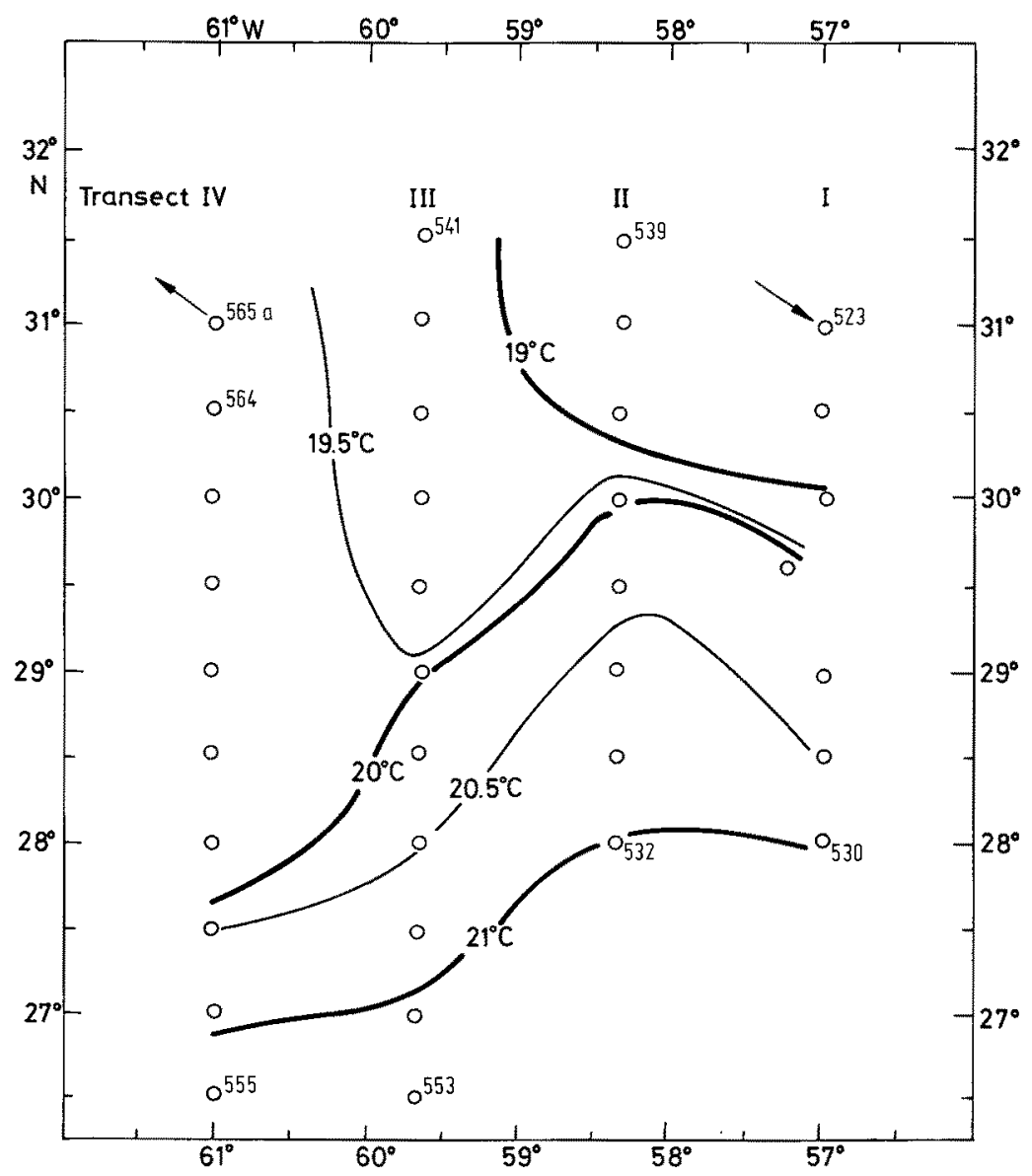

Fig. 1. Stationary grid of R. V. "Friedrich Heincke" and temperature distribution at $5 \mathrm{~m}$ depth in the central Sargasso Sea 


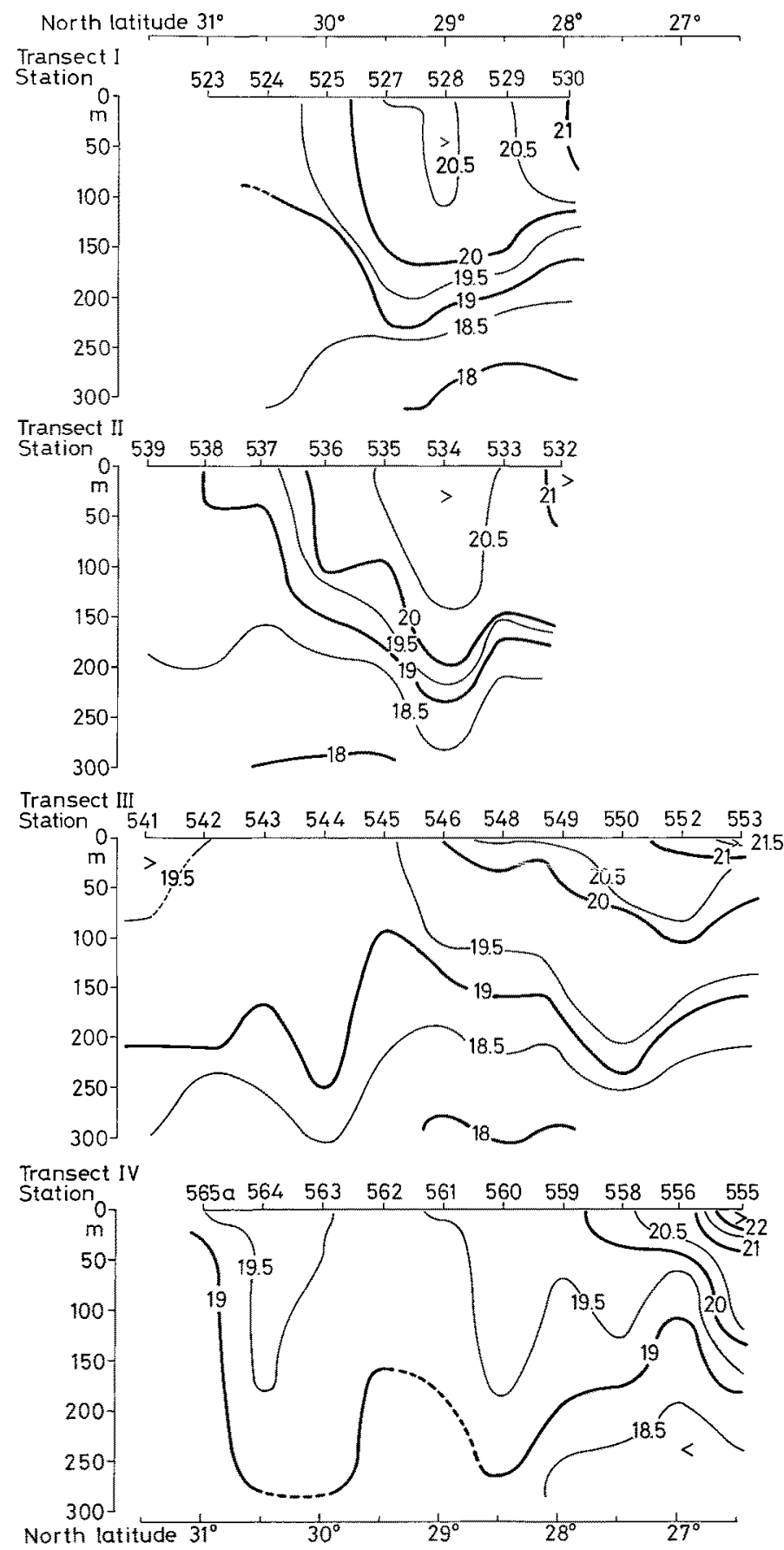

Fig. 2. Temperature distribution along four north-south transects in the central Sargasso Sea 
Along Transects I and II, on which only the $55 \mu \mathrm{m}$ mesh net samples of the northernmost and southernmost stations were evaluated, the same general picture of a vertically homogeneous water column in the north and a more stratified water to the south is apparent. The $20^{\circ} \mathrm{C}$ isotherm at the surface may be taken as the line separating the two types of temperature regimes.

\section{Plankton biomass}

The distribution of invertebrate plankton biomass, excluding molluscs and vertebrates, in the upper $200 \mathrm{~m}$ along Transects III and IV is depicted in Figure 3 . The dots

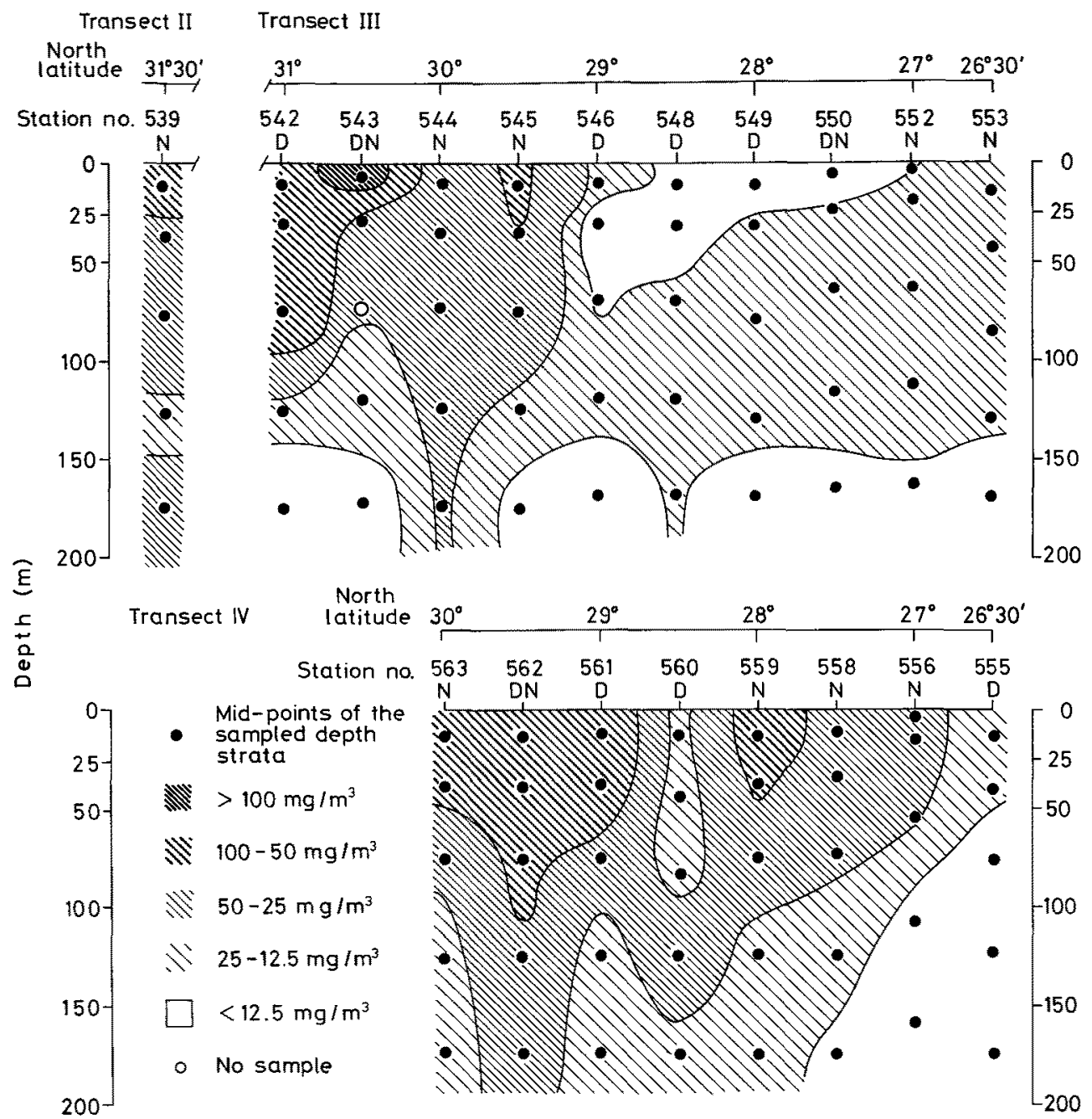

Fig. 3. The 100 um mesh net plankton, excluding molluscs and vertebrates. Horizontal and vertical distribution of plankton biomass (wet weight in $\mathrm{mg} / \mathrm{m}^{3}$ ) along two north-south transects in the central Sargasso Sea. $(\mathrm{D}=$ day, $\mathrm{N}=$ night, $\mathrm{DN}=$ dusk) 
Table 1. The $100 \mu \mathrm{m}$ mesh net plankton, excluding molluscs and vertebrates. Average concentrations of biomass (wet weight in $\mathrm{mg} / \mathrm{m}^{3}$ ) for the upper $200 \mathrm{~m}$ at stations north and south of $20^{\circ} \mathrm{C}$ surface temperature in the Sargasso Sea. Values in brackets include the weight of single large organisms. $(\mathrm{D}=$ day, $\mathrm{N}=$ night, $\mathrm{DN}=$ dusk)

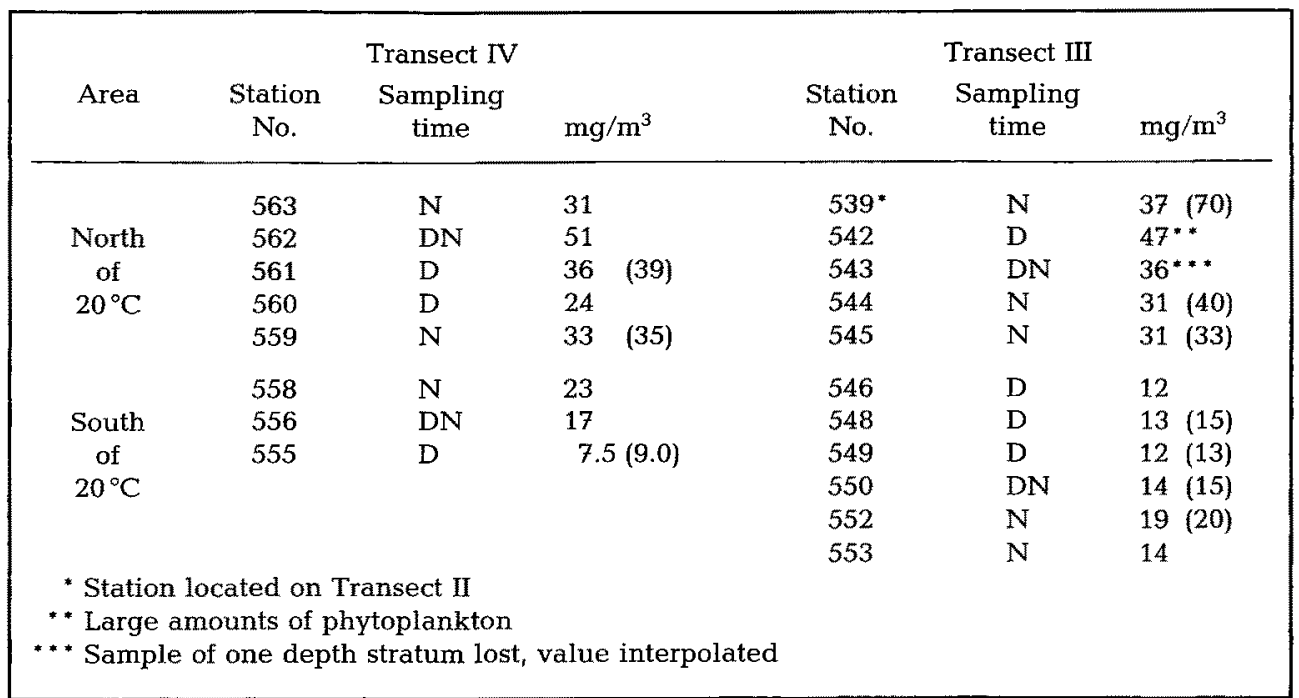

mark the mid-points of the sampled depth strata; the weights of isolated large organisms have been excluded. The average values for plankton concentrations over the whole $0-200 \mathrm{~m}$ depth range varied in the range of 7.5 and $51 \mathrm{mg} / \mathrm{m}^{3}$ (Table 1). At the stations north of the $20^{\circ} \mathrm{C}$ surface isotherm, where the vertical gradient between the surface and $200 \mathrm{~m}$ depth was less than $1^{\circ} \mathrm{C}$, the plankton biomass in the $0-200 \mathrm{~m}$ depth layer averaged to a median value of $34.5 \mathrm{mg} / \mathrm{m}^{3}$, with a range of individual values of $24-51 \mathrm{mg} / \mathrm{m}^{3}$ for this area. All the values from the stations south of this line, where the vertical temperature gradient increased to more than $1{ }^{\circ} \mathrm{C}$, fell into the range $7.5-23 \mathrm{mg} /$ $\mathrm{m}^{3}$ with a median of $14 \mathrm{mg} / \mathrm{m}^{3}$. They were thus consistently lower, differing on an average by a factor of 2.5 (Table 2 ).

Table 2. The $100 \mu \mathrm{m}$ mesh net plankton, excluding molluscs and vertebrates. Median values for the average concentration of plankton biomass (wet weight in $\mathrm{mg} / \mathrm{m}^{3}$ ) for the $0-200 \mathrm{~m}$ depth layer north and south of the $20^{\circ} \mathrm{C}$ surface isotherm. Values in brackets include the weight of single large organisms

\begin{tabular}{|c|c|c|c|c|c|}
\hline \multirow[t]{2}{*}{ Samples } & \multicolumn{2}{|c|}{ North } & \multicolumn{2}{|c|}{ South } & \multirow{2}{*}{$\begin{array}{c}\text { North: South } \\
\text { ratio }\end{array}$} \\
\hline & $\begin{array}{c}\text { No. of } \\
\text { samples }\end{array}$ & $\mathrm{mg} / \mathrm{m}^{3}$ & $\begin{array}{c}\text { No. of } \\
\text { samples }\end{array}$ & $\mathrm{mg} / \mathrm{m}^{3}$ & \\
\hline All samples & 10 & 34.5 & 9 & 14 & 2.5 \\
\hline Daytime samples & 3 & $36 \quad(39)$ & 4 & $12 \quad(12.5)$ & $3.0\{3.1\}$ \\
\hline Nighttime samples & 5 & $31 \quad(35)$ & 3 & $19 \quad(20)$ & $1.6(1.8)$ \\
\hline Dusk samples & 2 & 43.5 & 2 & $15.5(16)$ & $2.8(2.7)$ \\
\hline Night: day ratio & & $0.86(0.90)$ & & $1.6(1.7)$ & \\
\hline
\end{tabular}


The plankton was collected at various times of day and night. In order to consider possible diurnal effects in the samples, the results were grouped into three categories. The daytime collections include all the samples taken after sunrise and until one hour before sunset. Nighttime collections encompass the time from one hour after sunset to one hour before sunrise. Dusk samples were taken during the two hour period around sunset (i:e. 17.00-19.00 hours). No samples were taken at dawn.

As shown in Table 2, for all time categories, the north-south differences in plankton concentrations were consistent in direction, but appear to be most pronounced during day. Since the proportion of day and night samples differed in both areas, the overall north: south ratio of $2.5: 1$, obtained by combining all samples irrespective of the sampling time, might be biased to some degree.

This comparison does not include results from the two northernmost and two southernmost stations, one sampled during the day, the other at night in each area. The biomass values, given in Table 3 , include molluscs and vertebrates. Thus, they are not exactly comparable with the previous ones, though the difference seems to be minor. Based on this set of outermost stations on Transects III and IV, a more pronounced north : south ratio of about $4: 1$ was calculated for the average biomass density in the 0-200 m depth zone.

The vertical distribution of plankton biomass in the 0-500 $\mathrm{m}$ depth zone presented in Table 3 shows the maximum concentration to be in the upper $100 \mathrm{~m}$. Below this depth, a more or less sharp decrease in biomass is apparent, which results in a difference of about one order of magnitude between the $0-100 \mathrm{~m}$ and $400-500 \mathrm{~m}$ layer.

The samples from a larger number of stations, at which sampling was restricted to the upper $200 \mathrm{~m}$, revealed a wide range of variation in the vertical distribution of plankton biomass within this depth range (Fig. 3). On the average, two thirds of the total plankton biomass was concentrated in the upper $100 \mathrm{~m}$. No pattern in time but in space is indicated from the observed differences. The vertical gradient in biomass appears to be less pronounced in the more stratified waters south of the $20^{\circ} \mathrm{C}$ surface isotherm as compared to the homogeneous waters north of this line.

Table 3. The $100 \mu \mathrm{m}$ mesh net plankton, including molluscs and vertebrates. Vertical distribution in density by number $\left(\mathrm{A}=\mathrm{No} . / \mathrm{m}^{3}\right)$ and biomass $\left(\mathrm{B}=\right.$ wet weight in $\left.\mathrm{mg} / \mathrm{m}^{3}\right)$ north and south of the $20^{\circ} \mathrm{C}$ surface isotherm $(\mathrm{D}=$ day, $\mathrm{N}=$ night). Note that zooplankton abundance and biomass do not represent the same sample in the depth strata $0-100 \mathrm{~m}$ and $100-200 \mathrm{~m}$

\begin{tabular}{|c|c|c|c|c|c|c|c|c|}
\hline \multirow{3}{*}{$\begin{array}{c}\text { Station } \\
\text { Depth (m) }\end{array}$} & \multicolumn{4}{|c|}{ North } & \multicolumn{4}{|c|}{ South } \\
\hline & \multicolumn{2}{|c|}{$\begin{array}{c}565 a \\
D\end{array}$} & \multicolumn{2}{|c|}{$\begin{array}{c}564 \\
\mathrm{~N}\end{array}$} & \multicolumn{2}{|c|}{$\begin{array}{c}555 \\
\mathrm{D}\end{array}$} & \multicolumn{2}{|c|}{$\begin{array}{c}553 \\
\mathrm{~N}\end{array}$} \\
\hline & $\mathrm{A}$ & B & $\mathrm{A}$ & B & $\mathrm{A}$ & B & A & B \\
\hline $0-100$ & 2700 & 99 & 2800 & 94 & 400 & 14 & 900 & 28 \\
\hline $100-200$ & 620 & 19 & 520 & 30 & 290 & 5.0 & 600 & 12 \\
\hline $200-300$ & 140 & 5.6 & 740 & 25 & 7.7 & 2.0 & 57 & 5.5 \\
\hline $300-400$ & 21 & 4.9 & 49 & 3.3 & 17 & 1.4 & 21 & 1.3 \\
\hline $400-500$ & 12 & 9.4 & 40 & 3.7 & 0.72 & 1.1 & 7.6 & 1.7 \\
\hline Mean $0-500$ & 700 & 27 & 860 & 32 & 145 & 4.7 & 320 & 9.7 \\
\hline
\end{tabular}


The biomass values for invertebrate plankton presented in this study are within the range of wet weight data reported in the literature for the central Sargasso Sea (Bé et al., 1971). Compared to the smallest mesh sizes $(150-200 \mu \mathrm{m})$ so far used for net samples in this area, the $100 \mu \mathrm{m}$ net does not seem to add any important fraction to the total biomass. This will be different with respect to numbers as described below.

\section{Plankton abundance, composition and size distribution}

\section{$100 \mu \mathrm{m}$ mesh net plankton}

This section summarizes preliminary results of a more detailed analysis of $100 \mu \mathrm{m}$ mesh net plankton, based on the $500 \mathrm{~m}$ sampling profiles obtained on two northern and two southern stations ( $\mathrm{Tab} .3$ ). The mean density for all planktonic organisms caught in the upper $500 \mathrm{~m}$ was about 760 individuals $/ \mathrm{m}^{3}$ at the northernmost stations of the Transect III. This is double the number of organisms reported by Deevey (1971) and Deevey \& Brooks (1971) for $203 \mu \mathrm{m}$ mesh net plankton at station "S", located near Bermuda: the mean daytime value in springtime (March/April) over a three year period was about 350 organisms $/ \mathrm{m}^{3}$ (range: $210-580$ organisms $/ \mathrm{m}^{3}$ ). The greater numbers obtained in the present study are accounted for mainly by the smaller mesh size used during sampling. More than $50 \%$ of the total numbers of organisms caught were microcopepods and nauplii in the size group of less than $400 \mu \mathrm{m}$.

At the southern stations, the average density throughout the $500 \mathrm{~m}$ water column was about 220 organisms $/ \mathrm{m}^{3}$. Comparable data for this area are not available in the literature. The proportion of small organisms was about the same as it was north of the thermal front. Assuming that half the number of organisms would have been caught by $203 \mu \mathrm{m}$ mesh nets, based on the above comparison, the plankton density encountered south of the thermal front appeared to be lower than the lowest density encountered by Deevey (1971) to the north, in the Bermuda area.

Table 3 includes information on the vertical distribution of the organisms according to their numerical abundance. The continuous decrease in the density of organisms from the surface downward corresponds to that in biomass given above. The decline in number is more pronounced, however. The depth layer $0-200 \mathrm{~m}$ contained on an average $92 \%(80-97 \%)$ of all organisms sampled within the $500 \mathrm{~m}$ water column, and between the $0-100 \mathrm{~m}$ and $400-500 \mathrm{~m}$ depth layer the difference was about two orders of magnitude as compared to a decline of one order of magnitude in biomass.

Besides a possible shift to larger organisms with increasing depth, not indicated by the rather wide size categories used in the present study, the less pronounced decline in "biomass" is at least in part due to an increasing percentage of dead or damaged specimens at greater depths, which were not included in the counts but in the weights, and which sometimes outnumbered the fraction of living animals by nearly one order of magnitude.

The living copepod fraction (including nauplii) in the $0-500 \mathrm{~m}$ layer averaged for $75 \%$ and $87 \%$ of the total numbers of living organisms at the northern and southern stations, respectively. Corresponding densities of copepod exoskeletons and carcasses averaged 360 and 100 per $\mathrm{m}^{3}$, respectively. This is about $40 \%$ of all objects that might be counted as copepods, which is a far greater percentage than the $14.9 \%$ reported by Deevey (1971) for the upper $500 \mathrm{~m}$ as an annual mean. One reason for the greater number 
of copepod carcasses counted during the present study may certainly be the smaller mesh size used for sampling. On the other hand, it may also be interpreted as an indication of unfavourable hydrographic conditions (Weikert, 1977), which in this case could be due to the mixing of the water masses in the vicinity of the thermal front.

\section{$55 \mu \mathrm{m}$ mesh net plankton}

The abundance and composition of planktonic organisms at the four northern and four southern stations investigated using $55 \mu \mathrm{m}$ mesh nets are provided by Table 4 . The overall range of densities of organisms from the total of eight stations analysed was $1,400-14,000$ specimens $/ \mathrm{m}^{3}$. Systematic differences between day and night samples were not observed. The median concentration at the four northern stations was about three times higher than at the four southern stations.

The composition of the zooplankton according to major taxonomic groups seemed to be rather similar in both areas. Copepod nauplii accounted for $51-68 \%$ of the total numbers and copepodid stages I-VI for $28-42 \%$. Molluscs $(0.82-5.2 \%$ ) and appendicularians (1.1-7.8\%) alternated for the third and fourth ranks. All the other taxonomic groups listed in Table 4 accounted altogether for less than $2 \%$ of the total individual numbers. The group "larval forms" includes mainly unidentified trochophores and larval echinoderms and bryozoans, whereas larval stages of other organisms, such as salps and polychaetes, were included with their respective taxonomic groups. The group "molluscs" consisted mainly of pteropod larvae and juveniles. Lamellibranch larvae also occurred regularly, but in very small numbers.

Table 4 . The $55 \mu \mathrm{m}$ mesh net plankton in the upper $100 \mathrm{~m}$ of the Sargasso Sea: abundance $\left(\mathrm{No} . / \mathrm{m}^{3}\right)$ and composition of metazoan plankton

\begin{tabular}{|c|c|c|c|c|c|}
\hline \multirow[t]{2}{*}{ Organisms } & \multicolumn{2}{|c|}{ Northern stations $(\mathrm{N}=4)$} & \multicolumn{3}{|c|}{ Southern stations $(\mathrm{N}=4)$} \\
\hline & Median & Range & Median & & ange \\
\hline Coelenterates & 36 & $6.6-66$ & 8.2 & 7.9 & -11 \\
\hline Medusae & 16 & $3.5-39$ & 1.1 & 0.74 & $1-\quad 3.1$ \\
\hline Siphonophores & 13 & $3.1-41$ & 7.7 & 6.6 & $-\quad 7.9$ \\
\hline Crustaceans & 5400 & $2400-13000$ & 1900 & 1300 & -4100 \\
\hline Copepodids I-VI & 1750 & $850-5000$ & 785 & 490 & -1200 \\
\hline Copepod nauplii & 3600 & $1500-7900$ & 1100 & 830 & -2900 \\
\hline Ostracods & 13 & $8.4-26$ & 8.2 & 5.7 & -12 \\
\hline Other crustaceans & 8.6 & $0.88-\quad 22$ & 2.4 & 2.2 & $-\quad 4.4$ \\
\hline Molluscs & 110 & $21-180$ & 44 & $36-$ & -73 \\
\hline Tunicates & 140 & $28-1200$ & 50 & 29 & -98 \\
\hline Salps, doliolids & 10 & $0.44-\quad 87$ & 0.22 & 0 & 0.44 \\
\hline Appendicularians & 130 & $26-1100$ & 50 & 28 & -98 \\
\hline Miscellaneous & 38 & $6.2-140$ & 9.3 & 7.5 & -14 \\
\hline Chaetognaths & 26 & $3.5-110$ & 4.4 & 2.2 & 5.7 \\
\hline Polychaetes & 4.5 & $0.44-$ & 0.66 & $0.44-$ & 2.6 \\
\hline Larval forms & 7.7 & $2.2-$ & 4.6 & 4.0 & 5.3 \\
\hline Total & 5750 & $2400-14000$ & 2000 & 1400 & -4300 \\
\hline
\end{tabular}


Invertebrate plankton of the Sargasso Sea

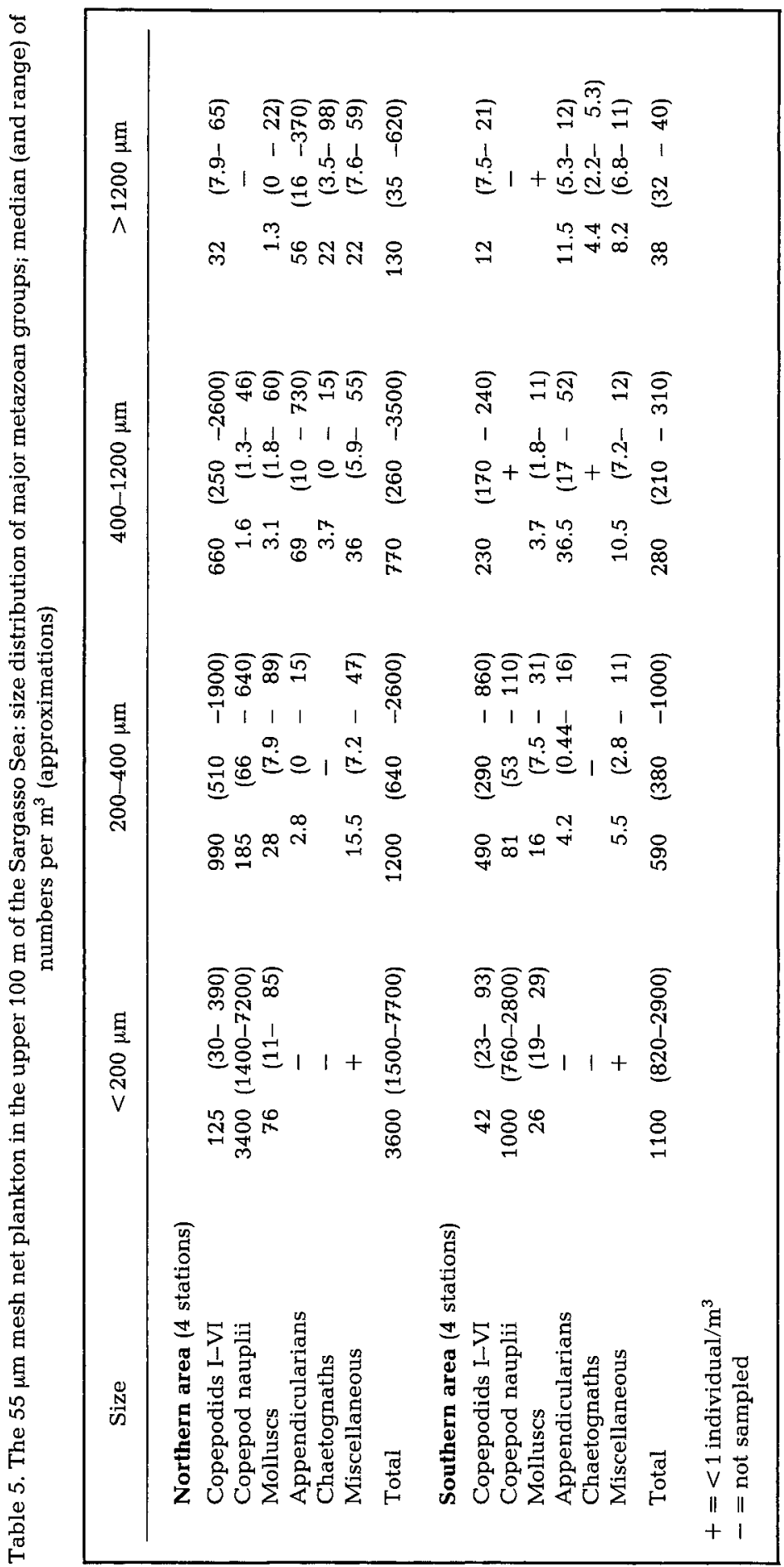


The size distribution of planktonic organisms within the major taxonomic groups is provided by Table 5 . Specimens smaller than $200 \mu \mathrm{m}$ (microzooplankton) accounted for $52-68 \%$ of the total number of all size groups. In this smallest size category, nearly all the organisms were copepod nauplii $(93-96 \%)$, microcopepods $(2.1-5.8 \%)$, or pteropod larvae $(0.7-4.5 \%)$. Tiny ostracods were occasionally noted.

Organisms $200-400 \mu \mathrm{m}$ in size (small mesozooplankton) had a relative abundance of $19-31 \%$. In this size class, small copepodids were most abundant (73-87\%), copepod nauplii ranked next $(7.0-25 \%)$ and pteropods third (1.2-9.5\%). The remaining organisms (1.3-3.1\%) consisted mainly of appendicularians, ostracods, small hydromedusae, polychaetes and various larval forms.

The size group 400-1,200 $\mu \mathrm{m}$, which accounted for $7.3-25 \%$ of the total number of organisms, was again dominated by small copepods and copepodids (72-93\%). Appendicularians increased in relative importance $(3.8-22 \%)$, whereas molluscs were less abundant, and copepod nauplii were nearly lacking. The remaining organisms accounted for $2.0-5.8 \%$. These were mainly ostracods, but they also included chaetognaths or salps. Most bryozoan larvae were in this size class.

The larger organisms of more than 1,200 $\mu \mathrm{m}$ accounted for only $0.75-4.3 \%$ of the total numbers. In contrast to the three smaller size classes mentioned above, the relative abundances of several taxonomic groups at the northern and southern stations seemed to be different. Appendicularians accounted for $40-62 \%$ of the total numbers within this class at the northern stations, but only $14-38 \%$ at the southern stations. Correspondingly, copepods showed a lower relative abundance in the northern area (11-28\%) than in the southern (23-55\%). Chaetognaths (5.8-19\%) and siphonophores $(4.7-20 \%)$ ranked third or fourth. The latter had a slightly higher relative abundance in the southern waters.

In general, the differences in abundance between the northern and southern stations are reflected in all size classes. With respect to major taxonomic groups, qualitative north-south differences are indicated in the largest size class only.

\section{DISCUSSION}

In the Sargasso Sea, the biomass of the plankton standing stock is generally considered to be low compared to adjacent areas in the Atlantic Ocean. Large scale comparisons of the invertebrate plankton fauna are based, in most cases, on pooled data from different parts of the Sargasso Sea. Bé et al. (1971) reviewed the earlier literature. The data they considered were obtained by sampling during various seasons, and no special attention was paid to the specific hydrographic situation at the time of sampling. Bé et al. noted, however, that in their own studies, the lowest values were always found in the "southwestern" part of the Sargasso Sea. According to their figures, this is an area between about 18 and $32^{\circ} \mathrm{N}$, and between 45 and $55^{\circ} \mathrm{W}$, a region, where permanent thermal stratification of the epipelagic zone can be expected.

More specific information required to relate the abundance of zooplankton in the Sargasso Sea to the thermal front is provided by Colton et al. (1975). Along a north-south transect sampled with a Hardy Plankton Recorder, the concentration of copepods north of the front averaged twice the value found at the stations south of the front. An equal or 
larger ratio was obtained during the present study considering $100 \mu \mathrm{m}$ and $55 \mu \mathrm{m}$ mesh net plankton.

The abundance of zooplankton in the northern area of the Sargasso Sea shows a definite seasonal cycle with highest concentrations, in terms of both number and biomass, during spring (Deevey, 1971; Deevey \& Brooks, 1971, 1977). This has been associated with the seasonal cycle of primary production which, in turn, can be related to the nutrient recycling in the upper waters during the winter mixing (Menzel \& Ryther, 1960). No comparable information is yet available for the southern part of the central Sargasso Sea. The permanent thermal stratification implies, however, that the seasonal changes should be less pronounced in this part than in the north.

From the above discussion, the necessity to distinguish between the northern and southern part of the Sargasso Sea is apparent, even in large scale regional comparisons of plankton abundance. A general problem regarding the comparability of data lies in the fact that the location of the thermal front can vary throughout an extensive geographic region. Its position has been observed between 24 and $32^{\circ} \mathrm{N}$ (Colton et al., 1975). It meanders irregularly and the sharpness of the frontal separation between the two water bodies varies considerably (Wegner, pers. comm.).

Published data on the abundance of micro- and small mesozooplankton from the Sargasso Sea are scarce. Plankton collections using a mesh size of $200 \mu \mathrm{m}$ or more fail to catch almost all the smallest copepods and the copepod nauplii (Deevey, 1971). Ortner et al. (1980) obtained small mesozooplankton from the upper $200 \mathrm{~m}$ in the northernmost Sargasso Sea with $67 \mu \mathrm{m}$ mesh nets in August and November. It can be seen from their graphs of the vertical distribution that the concentration of nauplii and microcopepods (i.e. smaller than $500 \mu \mathrm{m}$ ) in the 0-100 m depth layer was generally similar to that plotted during the present study, based on $55 \mu \mathrm{m}$ mesh net samples.

The smaller size fraction of metazoan plankton generally plays an important role as food for fish larvae (e.g. Arthur, 1977; Duka \& Gordina, 1973). It was originally attempted in the present study to assess this small zooplankton fraction in the Sargasso Sea as potential food supply for eel larvae. The spawning area of the American and European eel (Anguilla rostrata and $A$. anguilla) is located in the southern part of the Sargasso Sea, and recent studies by Schoth \& Tesch (1982) have demonstrated that the youngest larvae occur mainly in this area. However, not one single food organism has yet been found in the guts of the eel larvae. The information obtained on the concentration of small planktonic organisms may nevertheless be of interest because they represent a potential food supply for fish larvae of many species.

In the $0-100 \mathrm{~m}$ layer, median densities of nauplii, the most abundant group in the $55 \mu \mathrm{m}$ mesh samples, were 3,600 and 1,100 individuals $/ \mathrm{m}^{3}$ in the northern and southern areas, respectively. These concentrations are similar to those reported by Arthur (1977) from an important area of larval fish development in the Northeast Pacific. The mean concentration of nauplii in the upper $100 \mathrm{~m}$ of the California Current, based on sampling with $55 \mu \mathrm{m}$ mesh nets, was 2,800 individuals $/ \mathrm{m}^{3}$.

The nets were towed from $100 \mathrm{~m}$ to the surface, so the information provided can be viewed only as average values. Differences in density on a smaller scale may be very pronounced (Timonin, 1976). Arthur (1977) claimed that the small scale distribution of planktonic organisms may be a more important factor than the average density. Peaks in the concentration of microzooplankton may coincide, for instance, with seasonal deep 
chlorophyll maxima, as demonstrated in the temporarily stratified waters of the northernmost Sargasso Sea by Ortner et al. (1980). High chlorophyll concentrations at a depth of about $100 \mathrm{~m}$ during the summer stratification have also been reported for the area close to Bermuda (Menzel \& Ryther, 1960), which may cause respective concentration peaks of microzooplankton in this area. Similar information on the small scale distribution of chlorophyll and/or microzooplankton is not yet available for that part of the southern Sargasso Sea that is thermally stratified without seasonal variation.

Acknowledgements. I am indebted to Prof. Dr. D. Schnack for critically reading and discussing the manuscript. I also wish to thank Dr. F.-W. Tesch, the organizer of the Eel Research Program, G. Wegner, who kindly provided the temperature data, and Dr. C. Heckman, who streamlined the English manuscript. This investigation was supported by the Ministry for Research and Technology (Federal Republic of Germany). The results are part of a thesis to be submitted at the University of Hamburg.

\section{LITERATURE CITED}

Arthur, D. K., 1977. Distribution, size, and abundance of microcopepods in the California Current system and their possible influence on survival of marine teleost larvae. - Fish. Bull. U.S. 75, 601-611.

Backus, R. H., Craddock, J. E., Haedrich, R. L. \& Shores, D. L., 1969. Mesopelagic fishes and thermal fronts in the western Sargasso Sea. - Mar. Biol. 3, 87-106.

Bé, A. W. H., Forns, J. M. \& Roels, O. A., 1971. Plankton abundance in the North Atlantic Ocean. In: Fertility of the sea. Ed. by J. D. Costlow. Gordon \& Breach, New York, 1, 17-50.

Beers, J. R., 1976. Determination of zooplankton biomass. In: Zooplankton fixation and preservation. Ed. by H. F. Steedman. Unesco Pr., Paris, 35-84. (Monographs on oceanographic methodology. 4.)

Cifelli, R. \& Sachs, K. N. jr., 1966. Abundance relationships of planktonic Foraminifera and Radiolaria. - Deep-Sea Res. 13, 751-753.

Colton, J. B. jr., Smith, D. E. \& Jossi, J. W., 1975. Further observations on a thermal front in the Sargasso Sea. - Deep-Sea Res. 22, 433-439.

Deevey, G. B., 1971. The annual cycle in quantity and composition of the zooplankton of the Sargasso Sea off Bermuda. I. The upper $500 \mathrm{~m}$. - Limnol. Oceanogr. 16, 219-240.

Deevey, G. B. \& Brooks, A. L., 1971. The annual cycle in quantity and composition of the zooplankton off Bermuda. II. The surface to $2000 \mathrm{~m}$. - Limnol. Oceanogr. 16, 927-943.

Deevey, G. B. \& Brooks, A. L., 1977. Copepods of the Sargasso Sea off Bermuda: species composition, and vertical and seasonal distribution between the surface and $2000 \mathrm{~m}$. - Bull. mar. Sci. 27, 256-291.

Duka, L. A. \& Gordina, A. D., 1973. Abundance of ichthyoplankton and feeding of fish larvae in the Western Mediterranean and adjacent areas of the Atlantic Ocean. - Hydrobiol. J. 9, 54-59.

Hulburt, E. M., 1964. Succession and diversity in the plankton flora of the western North Atlantic. Bull. mar. Sci. 14, 33-44.

Katz, E. J., 1969. Further study of a front in the Sargasso Sea. - Tellus 21, 259-269.

Menzel, D. W. \& Ryther, J. H., 1960. The annual cycle of primary production in the Sargasso Sea off Bermuda. - Deep-Sea Res. 6, 351-367.

Ortner, P. B., Wiebe, P. H. \& Cox, J. L., 1980. Relationships between oceanic epizooplankton distributions and the seasonal deep chlorophyll maximum in the Northwestern Atlantic Ocean. - J. mar. Res. 38, 507-531.

Ryther, J. H. \& Menzel, D. W., 1960. The seasonal and geographic range of primary production in the western Sargasso Sea. - Deep-Sea Res. 6, 235-238.

Ryther, J. H. \& Menzel, D. W., 1961. Primary production in the southwest Sargasso Sea, January/ February 1960. - Bull. mar. Sci. 11, 381-388.

Schoth, M. \& Tesch, F.-W., 1982. Spatial distribution of 0-group eel larvae (Anguilla sp.) in the Sargasso Sea. - Helgoländer Meeresunters. 35, 309-320. 
Steedman, $H_{2} F_{x}$ 1976. Examination, sorting and observation fluids. In: Zooplankton fixation and preservation. Ed. by H. F. Steedman. Unesco Pr., Paris, 182-183. (Monographs on oceanographic methodology. 4.)

Tesch, F.-W., 1982. The Sargasso Sea Eel Expedition 1979. - Helgoländer Meeresunters. 35 , $263-277$.

Timonin, A. G., 1976. Study of the vertical microdistribution of oceanic zooplankton. - Okeanologija 16, 79-82.

Voorhis, A. D., 1969. Horizontal extent and persistence of thermal fronts in the Sargasso Sea. Deep-Sea Res. 16 (suppl.), 331-337.

Wegner, G., 1982. Main hydrographic features of the Sargasso Sea in Spring 1979. - Helgoländer Meeresunters. 35, 385-400.

Weikert, H., 1977. Copepod carcasses in the upwelling region south of Cap Blanc, N. W. Africa. Mar. Biol. 42, 351-355.

Weikert, H. \& John, H.-Ch., 1981. Experiences with a modified Bé multiple opening-closing plankton net. - J. Plankt. Res. 3, 167-176.

Wheeler, E. H. jr., 1967. Copepod detritus in the Deep Sea. - Limnol. Oceanogr. 12, 697-702. 